\title{
COMPLEXITY AS THE IMMUNENTAL PROPERTIES OF LOCAL SELF-GOVERNANCE PHENOMENON
}

\section{КОМПЛЕМЕНТАРНІСТЬ ЯК ІМАНЕНТНА ВЛАСТИВІСТЬ ФЕНОМЕНУ МІСЦЕВОГО САМОВРЯДУВАННЯ}

\section{Koltun Viktoriia ${ }^{1}$}

DOI: http://dx.doi.org/10.30525/978-9934-571-26-8_9

\begin{abstract}
The subject of research is complementarity as an inherent property of the phenomenon of local self-government. The purpose of the article is to determine the substantiation of approaches to the definition of the essence and specificity of complementarity in the processes of implementation of local self-government. The methodology of the research was chosen the theory of systems, the theory of organizations, a number of interdisciplinary approaches, in connection with the fact that the theoretical and methodological foundations as a science "Public Administration and Administration" in general, and its direction "Local government" are in an active development. The formation of the methodological tools of this study was based on a philosophical basis of holism, proceeding from the synergetic unity of the world. The main conclusions are as follows. It is proved that the attributive feature of the phenomenon of local self-government and, accordingly, of local self-government as its manifestations and elements, is complementarity. The complex of activities of local self-government bodies is a sequence of states realized by their essential properties, which is complementarity. Under the complementarity of local self-government, we understand their attributive ability to act as the subject of complementarity and mutual influence in the time continuum. It is substantiated that the term "complementary changes" that describes the dynamic component of the process of realization of functions of the system of local self-government, which can lead to an optimal state of interaction of the system of local self-government and its elements with other open dynamic systems and their elements, is an appropriate term for naming the activities of local
\end{abstract}

\footnotetext{
${ }^{1}$ Doctor of Science in Public Administration, Associate Professor,

Professor of the Department of Regional Government, Local Government and City Administration, National Academy of Public Administration by the President of Ukraine, Ukraine
} 
self-government bodies. The essence of institutional and functional complementarity of the system of local self-government is determined. The institutional complementarity of the system of local self-government involves the construction and consolidation in the law of the way of implementing interaction with other public administration bodies both at local and central levels. Institutional complementarity testifies to the organizational immanent unity of several relatively stable systems and does not reflect their movement in time. Attributive features of functional complementarity of the system of local self-government are as follows: it characterizes the process; can be formed and used situationally (on the basis of the principles of organizational and legal autonomy) as a mechanism of "response" to one or another "challenge" faced by any element of the system of local self-government; in contrast to the institutional, its initiators and actors can act not only legitimized control subsystem, but also any other (group of other) elements of the system of local self-government. The status of the category of complementarity as a universal and key temporal property of local self-government is determined. The principle of universality means that local self-government is always, at any point in time, complementarily open to interactions with other systems or their elements. The peculiarity of the "key" property means the presence of a number of others that are secondary and refined, detailing the general. The specific characteristic of the phenomenon of local self-government is revealed, which is the ability to constantly implement in time, the actual ability to act as the center of complementary connections, the main actor of complementary processes. It is substantiated that the effective vector of development of the system of local self-government is the implementation of the principle of complementarity through a free (based on the principles of organizational and legal autonomy) choice of the optimal complimenter - expedient for a certain period of time to the subject II, which will be the most moderate for the subject I a system of local self-government.

\section{Introduction}

Актуальність даного дослідження обумовлюється рядом факторів об'єктивного характеру. Так, зважаючи на той факт, що теоретико-методологічні основи як науки «Публічне управління та адміністрування» в цілому, так і іiі напряму «Місцеве самоврядування» знаходяться на стадії бурхливого розвитку, виникає об'єктивна потреба у розширенні 


\section{Koltun Viktoriia}

існуючого понятійно-категоріального апарату. Зважаючи на інтердисциплінарний характер сучасних методологічних підходів, та виходячи із принципів єдності світобудови, вважаємо доцільним здійснювати пошук новітнього інструментарію у ряді суміжних наук, де ефективність застосування подібних засобів аналізу вже $є$ успішно доконаним фактом. Як довів проведений аналіз, потужний гносеологічний потенціал міститься у застосуванні поняття «комплементарність».

Саме тому, предметом даного дослідження є комплементарність як іманентна властивість феномену місцевого самоврядування. Метою визначено обгрунтування підходів до визначення сутності та специфіки комплементарності у процесах здійснення місцевого самоврядування. Методологією дослідження було обрано теорію систем, теорію організацій, ряд інтердисциплінарних підходів, зважаючи на відносну (у порівнянні у традиційними науками), молодість галузі знань «Публічне управління та адміністрування». Формування методологічного інструментарію даного дослідження грунтувалось на світоглядній основі холізму, що виходить із синергетичної єдності світу і уможливлює застосування методологічних комплексів суміжних наук. У зв'язку з вищевикладеним, основними завданнями даного дослідження стали наступні: проаналізувати комплекс змістів, що відносяться до поняття «комплементарності»; визначити доцільність та методологічний потенціал залучення до наукового обігу науки «публічне управління та адміністрування» кола понять, пов'язаних 3 «комплементарністю»; виявити специфіку застосування поняття «комплементарність» для феномену місцевого самоврядування; виходячи 3 атрибутивних властивостей місцевого самоврядування, визначити його кореляцію з проявами комплементарності.

\section{2. Комплекс змістів поняття «комплементарності»}

Поняття комплементарності останнім часом починає активно використовуватись у різних галузях знань, є складовою багатьох методологічних комплексів як загальнонаукового, так спеціального спрямування: у філософії, фізиці, хімії, генетиці, біології, психології, соціології, праві, економіці і менеджменті. Представники вищенаведених наук впевнено відстоюють необхідність застосування даного терміну у термінологічному апараті своїх досліджень. 3 метою обгрунтування доцільності застосування даного терміну у розвиткові 
методології науки публічне управління та адміністрування, нами було проведено аналіз результативності використання даного інструментарію у вказаних галузях знань.

«Термін комплементарність походить від латинського “complementum" - доповнення. Комплемент (від лат. Доповнення) - додатковий засіб; комплементарний - додатковий» [23, с. 217]. Комплементарність (біохім.) - взаємна відповідність в хімічні будові двох макромолекул, яка забезпечує їх взаємодію. Комплементарні структури підходять одна одній як ключ до замку [21, с. 621].

Даний термін у різних науках застосовується з дещо відмінним змістовним навантаженням. Наприклад, у математиці комплементарним називаються кути, що утворюють у сумі прямий «правильний», ідеальний кут. Свого часу вчені називали комплементарними такі кольори, які в результаті взаємодії утворювали білий - «ідеальний» колір. Комплементарність в молекулярній біології - взаємна відповідність, що забезпечує зв'язок доповнюючих одна одну структур [22]. У межах біохімії принцип комплементарності означає таку взаємну відповідність у структурі макромолекул, що дозволяє їм взаємодіяти. Так само широко розповсюдженим є дане поняття і у біології. Вперше термін був введений у науковий обіг Н. Бором при описі статусу частинки і хвилі. В останні десятиріччя комплементарність $\epsilon$ широко застосовуваним інструментом у філософії (роботи С. Фатєєвої, А. Цофнаса, А. Шоркіна); соціології (Е.А. Афонін, С.Г. Кірдіна) та економіці.

\section{3. Аналіз методологічної результативності використання поняття «комплементарність»}

Основні проблеми сучасної системи органів місцевого самоврядування (далі-OMC), викладені у [11], свідчать про недостатню результативність вибудуваних зв'язків між елементами ряду динамічних систем, якими є комплекси ОМС населеного пункту, регіону, тощо. На наш погляд, необхідно додати ще один параметр для характеристики i існуючих, і тих, що вибудовуються, зв'язків між ОМС, а саме - часовий вимір. Неврахування на сьогоднішньому етапі параметру темпоральності позбавляє вказані надсистеми їх сутнісної риси - складнісності. B.I. Аршинов «впевнений, що суттєвим кроком у нашому просуванні до розуміння складнісності з'явилося б звернення до темпоральності (в сенсі Пригожина)» [1]. 


\section{Koltun Viktoriia}

Ми не випадково звертаємося до класичних праць I. Пригожина, оскільки фундаментальна його ідея щодо синергетики вже стала базовою для сучасної методології науки. Водночас, дослідники вказують: «Проблема часу була для Пригожина у всіх відносинах центральною. «Це книга про час. На мій погляд, їй цілком підійшла б назва «Час забутий вимір», хоча деяким читачам такий заголовок здався б дивним» [20]. Такими словами I.Р. Пригожин починає свою книгу «Від існуючого до виникаючого». Для Пригожина ця проблема перебувала за межами класичної і навіть некласичної науки, але вже на передовій лінії становлення нової науки про складність, темпоральність» [1], пише B.I. Аршинов. Таким чином, уведення до методології науки «Державне управління» парадигми темпоральності, зокрема - у діяльності ОМС, виводить її на передову лінію світових здобутків.

Термін «комплементарність» застосовується у сучасній географічній науці при формуванні методологічних підходів до обгрунтування новітніх напрямів досліджень синкретичних єдностей, якими є, наприклад, геоекосистеми [14].

С. Бір, класик кібернетики, описував неможливість розв'язати проблему кореляції керуючої і керованої підсистем в умовах постійно змінюваного середовища (як екзогенного відносно комплексу керуюча-керована підсистема, так і частково-ендогенного, що впливає на одну з двох підсистем). Наслідком його роздумів і практичних розробок став запропонований ним (вперше для $30 \mathrm{x}$ pp. XX ст.) принцип зовнішнього доповнення для подібних систем: «Для побудови істинних кібернетичних машин, призначених для вироблення стратегічних рішень, буде необхідним принцип... зовнішнього доповнення, адже він являє собою практичний метод подолання наслідків теореми неповноти» [4]. Даний принцип застосовується нами у дослідженні в якості парадигми комплементарності місцевого самоврядування.

Таким чином, можна стверджувати факт трансляції термінологічного інструментарію з природничих наук у блок гуманітарних i, більш вузько, наук, які займаються питаннями управління. Однак, як буде показано далі, у науці «публічне управління та адміністрування» термін комплементарність не є достатньо вживаним, що, на наш погляд, дещо звужує методологічний інструментарій цієї галузі.

Ідея пошуку іманентної цілісності є притаманною онтологічним науковим розвідкам. Так само, як Всесвіт і окрема особистість прагне 
довершеності у віднайдені своєї повноти (за К. Марксом і В.П. Івановим), кожен суспільний феномен об'єктивно потребує стану комплементарності, будучи потенційно відкритим для взаємодії з іншими динамічними відкритими системами. Тому на когнітивному рівні у межах спеціальних наук комплементарність також виступає окремим предметом досліджень. Так, дане поняття широко застосовується у соціології «де процес виникнення малих груп... грунтується перш за все на комплементарності індивідів» (Т. Лірі). У психології використовується у класичних працях, наприклад, Е. Берна, Тоумена, Ж. Піаже. На суміжних гранях філософії, культурології, економіки і психології - глибоко опрацьовано С.В. Фатєєвою. Дослідниця аналізує існуючі підходи до універсального розуміння принципу комплементарності і зазначає: «ще В. Гейзенберг відстоював думку, що додатковість має універсальний характер. М. Борн вважав, що ідея додатковості має всезагальне значення, оскільки існує багато сфер людської діяльності, де один і той саме факт може розглядатися у різних, але взаємодоповнюючих аспектах. Він був згоден з Н. Бором у тому, що уявлення про додатковість можливо застосовувати у інших сферах знання, зокрема, у біології, психології, філософії, політиці» [22].

Зважаючи на статус філософії як «загальної методології науки», почнемо розгляд 3 неї. Розуміння комплементарності як взаємодоповнення, що має глибинний, іманентний характер, відображено у ряді філософських публікацій як сучасних вчених, так і всесвітньовідомих класиків. Наприклад, з точки зору Г. Лейбніца, комплементарність $\epsilon$ способом представлення всезагального як процесу взаємодоповнення індивідуальних явищ до цілого [15]. На думку ряду зарубіжних вчених, «запропонований Ф. Енгельсом закон єдності і боротьби протилежностей у рамках діалектичного матеріалізму найбільш близько описує поняття комплементарності» [7]. У вітчизняних філософських дослідженнях термін «комплементарність» також починає активно застосовуватись: «Пошук зв’язності...є характерним, перш за все, прагненням встановити комплементарність явищ культури - їх синхронізовану з'єднаність в упорядковану цілісність [25]. У контексті нашого дослідження інтерпретація є доцільною як «комплементарність процесів місцевого управління у синхронізованій єдності в упорядкованій цілісності». Такий підхід вбачається обгрунтованим для побудови системи управління на місцях, реалізовуваній як комплекс 


\section{Koltun Viktoriia}

функцій та повноважень ОМС і МOBВ на основі комплементарного підходу.

На думку американського філософа Р. Бернстайна, є доцільним для відображення повноти світу застосування терміну «констелляція», який, з точки зору С.В. Фатєєвої, він запозичив з робіт Т. Адорно і В. Беньяміна. Однак, Р. Бернстайн наповнює це поняття дещо іншим змістом, потрактовуючи його як «групу сусідніх, змінних елементів, які чинять спротив приведенню до спільного знаменника, невід'ємної суті або первинному принципу, що все породжує - (переклад наш. B.K.)» [29].

У сучасних правових дослідженнях термін комплементарність також застосовується, але вже з іншим змістовним відтінком - як фактор соціальних співрегуляторів (через кореляцію норм права і моралі); як характеристика юрисдикції того чи іншого суду (наприклад, «Принцип комплементарності юрисдикції Міжнародного кримінального суду» описаний Н.В. Дрьоміною [8]. Л.О. Корчевна розглядає новітню, всеохоплюючу концепцію права на основі принципу комплементарності. Зазначена мета реалізується вченим через осмислення різноджерельного права або різних юрисдикцій в межах одного суспільного устрою [13, с. 1]. Таким чином, дослідження у галузі права увагу акцентують, головним чином, на таких аспектах комплементарності, що зумовлені іiі синтезуючими властивостями.

Сучасна психологія розглядає принцип комплементарності у контексті «обгрунтованого розподілу освітнього матеріалу за... модальностями... при проектуванні електронних підручників» У контексті «набуття знань принцип комплементарності означає таку організацію навчального матеріалу, яка забезпечує вільні взаємопереходи між загальним (абстрактним) і частковим (конкретним)» [17].

\section{4. Специфіка застосування поняття «комплементарність» для феномену місцевого самоврядування}

Зважаючи на методологічну цінність комплементарного підходу, вважаємо доцільним покласти цей принцип не тільки у феноменальну основу організації процесів управління на місцевому рівні, витлумачених як взаємодія ОМС і місцевих органів виконавчої влади (далі $M O B B)$, спрямована на розвиток територій, але і у когнітивну складову, в якості інструменту освіти і підвищення кваліфікації виборних 
і посадових осіб ОМС та державних службовців. У такий спосіб буде забезпечено принцип єдності світобудови та світосприйняття.

Є.Б. Герасимова, описуючи застосування розглядуваного нами поняття зазначає: «В управлінні персоналом, у промисловій психології комплементарність поведінки керуючого суб'єкту полягає у його прагненні максимально наблизити реальне протікання процесу до нормативного. Тут комплементарність використовується нарівні $з$ синонімічним йому поняттям процесуальної додатковості» [6]. Поняття «комплементарність» у менеджменті застосовується як принцип формулювання цілей організації і передбачає, що досягнення однієї цілі полегшує досягнення іншої [6].

Відомий методолог науки С.В. Фатєєва зазначає, що «особливого значення у сучасній економічній культурі набула ідея комплементарності, взаємодії на противагу жорстким уявленням щодо антиномій класових різниць...» [22]. На наше переконання, виглядає слушною думка щодо розповсюдження такого своєрідного «толерантного», тобто без вимоги взаємовиключення, підходу до інших, позаекономічних сфер суспільного буття.

Зважаючи на очевидну роль керуючої підсистеми суспільства, значну питому вагу функцій якої на місцях реалізує система місцевого самоврядування (далі - MC), видається доцільним розглядати категорію комплементарності в якості універсальної і ключової тенденції місцевого самоврядування. Принцип універсальності означає, що місцеве самоврядування, витлумачене і в якості феномену, і в якості системи, завжди є комплементарно відкритим до взаємовпливів 3 іншорідними системами або їх елементами. Застосовуючи поняття «ключової» тенденції ми мали на увазі наявність ряду інших, які є вторинними, похідними, залежними, такими, що уточнюють і деталізують генеральну властивість.

У [10] нами аналізуються трансформаційні процеси у системі місцевого самоврядування на основі підходів, що пропонує квантова фізика і квантова механіка. Застосування обраного інструментарію видається цілком обгрунтованим не тільки завдяки проведеній верифікації одержаних результатів та розширення традиційного кола методологічних інструментів науки державного управління, але і через наявність спільного онтологічного та гносеологічного підгрунтя принципу комплементарності, що є наскрізним атрибутом буттєвих 


\section{Koltun Viktoriia}

феноменів і когнітивних механізмів, які здатні забезпечити адекватне відображення і пізнання дійсності. Так, у роботах В.В. Налимова [18] 3 квантової механіки доведено, що однієї логічної конструкції, якою би досконалою вона не була, є недостатньо для опису складності світобудови. В результаті виникають підходи до багатозначних логік, розроблені Д. Бочвара, Я. Лукасевичем, Е. Пост і рядом інших вчених, за якими принципи класичної, аристотелівської логіки вже не мають абсолютного значення [22].

Близьким до кола досліджуваних нами проблем як практичного рівня (тенденції розвитку місцевого самоврядування), так і теоретико-методологічного (введення у науковий обіг науки публічне управління та адміністрування терміну комплементарність) є поняття «глокалізація», запропоноване британським соціологом Р. Робертсоном, яким він позначає два взаємодоповнюючих, комплементарних процеси - глобалізацію та регіоналізацію [31].

У сучасній політології до поняття комплементарності звертається К.Ф. Завершинськ, обгрунтовуючи необхідність методологічної комплементарності у дослідженні динаміки політичних інститутів [9]. На нашу думку є доцільним застосовувати когнітивний потенціал поняття комплементарності для дослідження складних відкритих динамічних систем і відповідних процесів, що відносяться до сфери публічного управління.

Серед сучасних економістів увагу поняттю комплементарності приділяють дослідники, які працюють у сфері маркетингу та менеджменту, наприклад І.А. Кораблинова, М.В. Лиходед, А.І. Цапко [12]. Концепція інституціональної комплементарності в економіці розробляється нашим сучасником і співвітчизником В.В. Ліповим. До зарубіжних класиків цієї концепції відносять Б. Амабле [27], М. Аокі [29], П. Холла і Д. Соскіса [30]. Як зауважує В.В. Ліпов, їх «об'єднує відмежовування дослідження економічної сфери від інших складових соціально-економічних систем» [16]. 3 точки зору В.В. Ліпова, «Комплементарність грунтується на зв'язках і взаємодіях, які мають впорядкований характер, об'єднаних на постійній основі і таких, що забезпечують цілісність, внутрішню диференціацію, самоідентифікацію і саморозвиток економічних систем у процесі господарювання» [16]. Принагідно зазначимо, що взаємодія як така це «вплив об'єктів один на одного, їх взаємообумовленість і породження одним об'єктом 
іншого; універсальна форму руху, розвитку, яка визначає існування і структуру будь-якої матеріальної системи» [24].

Стійкість будь-якої системи, у т. ч. системи місцевого самоврядування, є одним із аспектів, що характеризує ії ефективність, тобто здатність досягати власних цілей. Оскільки ефективність місцевого самоврядування визначено метою сучасного етапу державної політики у сфері місцевого самоврядування, видається доцільним здійснити аналіз підходів до формування та забезпечення стійкості системи МС на основі пропонованого нами у дослідженні принципу комплементарності із застосуванням окремих елементів інструментарію суміжних наук.

Стійкість ряду економічних феноменів давно перебувають у центрі уваги вчених, однак параметр стійкості як характеристика ефективних керуючих підсистем у галузі науки державне управління достатньою мірою не висвітлено. Вважаємо, що динамічний стан стійкості, iii комплексність забезпечується принциповою комплементарністю відкритої динамічної системи місцевого самоврядування. Водночас, 3 метою забезпечення відповідності когнітивного рівня феноменологічному, видається доцільним зосереджувати увагу не тільки на об'єктивній комплементарності системи МС як такої, але і комплементарному характеру чинників-процесів, які забезпечують вказані властивості, i на взаємодоповнюючому характері застосовуваного комплексу методологічних інструментів, які використовуються для аналізу вказаних явищ і процесів.

Для деталізації дослідження варто розмежовувати специфіку стійкості системи МС в широкому розумінні слова, за яким вона передбачає комплекс явищ, об'єктів і процесів, та систему ОМС того чи іншого населеного пункту, що пов'язана також із стійкістю окремого органу МС. Якщо оцінювати відповідність параметру стійкості всієї системи $\mathrm{MC}$ цілком, або навіть системи ОМС окремого населеного пункту, то є досить складним завданням забезпечити об'єктивність оціночних суджень, зважаючи на відсутність верифікованої системи критеріїв. Водночас, стійкість до зовнішніх впливів окремого ОМС може бути витлумачена як результат ефективного менеджменту. Зазначимо, що стійкість окремого ОМС характеризується через динамічний аспект, адже управлінські рішення щодо специфіки стійкості приймаються перманентно в якості реакції на постійно оновлювану інформацію, яка надходить $з$ ендогенного і екзогенного середовищ. 


\section{Koltun Viktoriia}

Однак, як показує проведений аналіз, стійкість і окремого елементу системи МС і системи в цілому, забезпечується через домірність процесів ендогенного середовища до симетричних процесів екзогенного середовища. Тому варто розглядати феномен стійкості через динамічну характеристику організації - процес, який має бути синхронним до комплексу процесів екзогенних середовищ. Вказану синхронність вбачається можливим досягнути шляхом вбудовування комплементарних процесів до керованої структури (організації чи процесу).

3 точки зору С.Б. Герасимової, «варто звернути увагу на неспівпадіння понять «стабільність» і «стійкість». Стабільність - стан матеріальних об'єктів, для яких збереження заздалегідь заданих параметрів $є$ умовою функціонування. Стійкість - стан, більш близький до рівноважного» [6]. На думку дослідниці, «якщо рівновага характеризується стійкістю, то додаткове регулювання є необов'язковим... Якщо рівновага не володіє властивістю стійкої рівноваги, то при збуреннях зовнішнього середовища, іiі регулювання є необхідним» [6].

Проведений аналіз доцільності застосування теорії стійкого розвитку до проблематики функціонування місцевого самоврядування виявив, що місцеве самоврядування, витлумачене і на рівні феномену, і на рівні системи, за рахунок синкретичної комплементарності, яка виступає його атрибутивною ознакою, здатне вибудовувати новий рівноважний стан через формування взаємодії з різноманітними елементами різнопорядкових («іншорідних» за М.Д. Кондратьєвим) середовищ.

«Особливої значущості набуває комплементарність інститутів за умов якісної різнорідності елементів системи світового господарства та багатоваріантності еволюційних трендів глобального розвитку», пише [7]. Запропоноване бачення доцільності комплементарності різнорідних інституцій дозволяє використати здійснений вказаний крок у економічній теорії для розвитку методології науки державне управління. Загальновідомо, що сьогодні відсутні єдині усталені підходи щодо розуміння іманентних зв'язків між природою феноменів місцевого самоврядування і державної влади. Відомі вітчизняні вчені О.В. Батанов і В.І. Борденюк, зокрема, дотримуються діаметрально протилежних поглядів. Якщо В.I. Борденюк стоїть на позиціях державницької концепції, то О.В. Батанов є яскравим послідовником громадівської.

Ми не випадково звернулися до таких дихотомічних підходів, адже ще Аристотелем було розроблено теорію різних видів проти- 
лежностей - від контрадикторності до контрарності, різниця між спектром яких полягає, фактично, у факті «взаємовиключності» або iii відсутності. Зважаючи на подібний за широтою спектр підходів до розуміння сутності на феноменальному рівні явищ «самоврядності» i «державності» як таких, вважаємо за доцільне аналізувати їх взаємовпливи і взаємодію через поняття комплементарності. Невипадково девізом Копенгагенської школи фізики стали слова “Contraria sunt complementa!" (Протилежності суть додатковості!).

Сучасне звучання і поглиблене розуміння слів Гегеля щодо єдності і боротьби протилежностей надав Нільс Бор, спираючись на принцип невизначеності Вернера Гейзенберга. Відомий фізик написав: «існує ... дилема щодо властивостей електронів і фотонів, де ми стикаємося 3 протиріччям, яке виявляється при порівнянні результатів спостереження над атомним об'єктом, одержуваних за допомогою різних експериментальних установок. Такі емпіричні вказівки свідчать про наявність співвідношень нового типу, що не мають аналогів в класичній фізиці, які зручно позначити терміном додатковість, щоб підкреслити ту обставину, що в суперечать один одному явищах ми маємо справу з різними, але однаково істотними аспектами єдиного чітко визначеного комплексу відомостей про об’єктах» [5]. Варто зауважити, що сучасна методологія ряду наук користується, крім терміну комплементарність, деякими його синонімами - «Принцип додатковості»; «Копенгагенська інтерпретація» квантової теорії; «Принцип комплементарності Нільса Бора», тощо.

Саме тому вбачається доцільним використовувати термін комплемен-тарність для позначення мультифакторної і поліваріантної взаємодії феномену місцевого самоврядування. Адже, як буде доведено далі, традиційне розуміння категорії комплементарності описує також поліваріантні види дихотомій - від протилежності до взаємодоповнення. Таким чином, обраний нами підхід забезпечить достатню об'єктивність щодо широкого спектру розумінь іманентного зв'язку феноменів місцевого самоврядування і державності.

Відомий методолог науки С.В. Фатєєва зазначає, що «особливого значення у сучасній економічній культурі набула ідея комплементарності, взаємодії на противагу жорстким уявленням щодо антиномій класових різниць...» [22]. На наше переконання, виглядає слушною думка щодо розповсюдження такого своєрідного «толерантного», тобто без вимоги 


\section{Koltun Viktoriia}

взаємовиключення, підходу до інших, позаекономічних сфер суспільного буття. Зважаючи на очевидну роль керуючої підсистеми суспільства, значну питому вагу функцій якої на місцях реалізує система МC, видається доцільним розглядати категорію комплементарності в якості універсальної і ключової тенденції місцевого самоврядування. Принцип універсальності означає, що місцеве самоврядування, витлумачене і в якості феномену, і в якості системи, завжди є комплементарно відкритим до взаємовпливів з іншорідними системами або їх елементами. Застосовуючи поняття «ключової» тенденції ми мали на увазі наявність ряду інших, які є вторинними, похідними, залежними, такими, що уточнюють і деталізують генеральну властивість.

Видатний дослідник проблем державного управління Г.В. Атаманчук пише: «При аналізі управління через управлінську діяльність припускаються однієї великої помилки, яка полягає у тому, що управлінська діяльність будь-якого суб'єкту влади (органу державної влади або органу місцевого самоврядування...) розглядається ізольовано від управлінської діяльності інших суб'єктів влади, як дещо автономне і самостійне. До розгляду майже не приймається той очевидний факт, що всі суб'єкти влади взаємопов'язані і взаємозалежні...» - (nереклад наш - В.К.) [2, с. 35] «тому у реальній дійсності між суб'єктами влади ...iде постійна взаємодія...тільки майстерність узгодження керуючих впливів з іншими суб'єктами влади дає можливість раціонально і глибоко впливати...не керовані об'єкти» [2, с. 35].

На наше переконання, застосування терміну «комплементарність» для визначення специфіки характеру взаємодії між ОМС і MOBВ ті іншими суб'єктами територіального розвитку цілком вирішує названу вченим проблему. «Реальна проблема полягає у чіткому, обгрунтованому визначенні місця і ролі кожного суб'єкту управління і системному узгодженні їх керуючих впливів» [2, с. 123]. Побудова системи місцевого самоврядування на феноменальному рівні з урахуванням запропонованих у даному дослідженні підходів дозволить уникнути вказаних вченим ускладнень. Під комплементарністю ОМС розуміємо їх атрибутивну властивість до взаємодоповнення та взаємовпливів в часовому континуумі.

Сучасний вітчизняний вчений В.В. Ліпов вдало використовує методологічний потенціал комплементарності для аналізу взаємодії ринку і держави [16]. Дослідник у цитованій статті розглядає вплив ринкових 
інститутів на формування інститутів державного устрою. При цьому вченим використовується поняття інституціональної комплементарності, яка відображає якість інтегративної цілісності соціально-економічних систем.

\section{5. Кореляція атрибутивних властивостей місцевого самоврядування та комплементарності}

Здійснена нами екстраполяція подібних інструментів на досліджувану сферу дозволяє сформулювати специфіку інституціональної та функціональної комплементарності, властивих системі МС. Так, інституціональна комплементарність системи МС передбачає заздалегідь вибудуваний і закріплений у законодавстві спосіб реалізації взаємодії з іншими органами публічного управління як місцевого, так і центрального рівнів. Подібні зв’язки визначено на рівні Конституції України, Законів України (у першу чергу - у Законі України «Про місцеве самоврядування в Україні» та «Про місцеві державні адміністрації»). Інституціональна комплементарність свідчить про організаційну іманентну єдність декількох відносно стабільних систем і не відображає їх рух у часі.

Натомість, функціональна комплементарність системи МС, як доводять результати проведених досліджень, суттєво відрізняється від інституціональної. Її специфічними рисами $є$ наступні: вона характеризує процес, тобто динаміку, а не статику, тому описується через «синхронізацію динамічних аспектів»; може формуватися і використовуватись ситуативно (на основі принципів організаційної і правової автономії) в якості механізму «відповіді» на той чи інший виклик, що постає перед будь-яким елементом системи МС; на відміну від інституціональної, iï ініціаторами і суб'єктами може виступати не тільки легітимізована керуюча підсистема (наприклад, місцева рада), але і будь-який інший (група інших) елементів системи МС; другою стороною комплементарності може виступати не тільки орган публічного управління, але і інша ТГ (наприклад, при реалізації функцій, передбачених Законом України «Про співробітництво територіальних громад») і громадська організація (рух) при реалізації тих чи інших функцій із забезпечення розвитку територій (наприклад, моніторингу і контролю).

На наш погляд, ключовим є поняття «кореляційного зв'язку», яке вибудовує логічну пов'язаність на когнітивному рівні між декількома об'єктами рівня феноменального. При цьому вважаємо, що кількість 


\section{Koltun Viktoriia}

об'єктів, які знаходяться у відносинах комплементарності є формально не обмеженою, адже, якщо виходити з розуміння необхідності постійного забезпечення домірності керуючої системи до керованої, система МС повинна постійно знаходитись у різних аспектах стану комплементарності, не тільки з іншими елементами системи публічного управління, але і з громадськими організаціями/рухами, з підприємницьким сектором, тощо.

Вітчизняний дослідник Д.С. Пілевич пише: «якщо говорити про комплементарні процеси, то, насамперед, необхідно виділяти основні та додаткові їх складові. Останні у свою чергу доповнюють, збагачують центральні елементи та частково, вступаючи у зв'язок з ними, створюють синергетичні ефекти для розвитку досліджуваного явища» [19]. Ми переконані, що аналіз специфіки місцевого самоврядування, витлумаченої через поняття комплементарності, виявляе його унікальну рису - постійно реалізовувану здатність, актуалізовану спроможність виступати центром комплементарних зв'язків, головним актором комплементарних процесів.

Згідно з основними положеннями теорії систем, аналіз будь-якої системи феноменів будується на використанні принципу комплементарності - «максимального наближення реального протікання процесу до ідеального. Комплементарність вивчає і вимірює синергетичний ефект, притаманний системам, що самоорганізовуються» [26]. У такому аспекті сучасну систему місцевого самоврядування варто розглядати як систему, що самоорганізовується на основі принципу комплементарності. Згідно із сучасними визначеннями, «Комплементарність - це відповідність, взаємодоповнюваність, взаємовідповідність. Комплементарність - у найбільш загальному сенсі - це філософське поняття, за допомогою якого протилежні теорії, концепції, явища і точки зору, які відображають різні погляди на дійсність, можливо представити у вигляді несуперечливої моделі» [7].

Найбільш ефективним вектором розвитку системи місцевого самоврядування можна вважати реалізацію принципу комплементарності шляхом вільного (на основі принципів організаційної та правової автономіі) вибору оптимального комплементора - доцільного та оптимального на певний період часу суб'єкту II, який у певний період часу буде найбільш домірним для суб'єкта I, який представляє систему місцевого самоврядування. 


\section{Complexity as the immunental properties of local self-governance...}

На думку [7] «концепція комплементарності виходить з того, що множина організацій, або послуг, або теорій, грунтуючись на різних системах відносин, взаємно доповнюють одна одну і можуть бути використані для побудови системи більш високого рівня. Кожна організація має власні системи цінностей, систему теоретичних і методологічних обгрунтувань реалізації власних стратегій. У цьому випадку комплементарність виявляється у внутрішній і зовнішній взаємодоповнюваності і залежності...на основі цього утворюється нова система більш високого рівня, яка забезпечує усіма необхідними параметрами обидві організації, доповнюючи або заміщуючи ті чи інші функції» [7].

Зважаючи на те, що вищенаведена думка дослідників стосується організацій комерційного сектору, для них справджується багатовекторність ідеологій, що може утруднювати формування цілісної системи. Водночас, застосування подібного підходу для забезпечення принципу комплементарності у системі МС, буде значно простішим, адже процес синхронізації елементів як самої системи МС, так і їх взаємодію з МОВВ буде відбуватись для однотипних (звісно, з урахуванням ряду відмінностей) місцевих органів публічного управління, що реалізовують як державну політику, так і власну діяльність, спрямовані на забезпечення комплексного соціально-економічного розвитку територій.

Перспективним підходом в організації здійснення системою МС своїх функцій на основі принципу комплементарності є використання аутсорсінгових технологій, описаних нами у [10] на прикладі спільного надання муніципальних адміністративних послуг ОМС і МOBВ.

Серед сучасних вчених, які займаються проблематикою менеджменту, а саме - управління підприємствами, варто виокремити А.В. Балабаниць і Д.В. Сай, праці яких присвячено актуальному як з методологічної, так і прикладної точки зору питанню - управлінню маркетингом взаємодії підприємств [3]. Вказані дослідники вибудовують технологію планування стратегічних змін в системі управління маркетингом взаємодії підприємств на основі моделі «Калейдоскоп» і матриці комплементарності стратегічних змін. У контексті нашого дослідження є вкрай важливим здобутком цитованих авторів застосування поняття «комплементарних змін», що вони застосовують при характеристиці взаємодії підприємств. 


\section{Koltun Viktoriia}

Здійснена екстраполяція подібного методологічного інструментарію на сферу місцевого самоврядування дає підстави для використання поняття «комплементарних змін» для характеристики динамічної складової процесу трансформації системи місцевого самоврядування, що здатна призвести до оптимального стану взаємодії системи МС/iї елементів з іншими відкритими динамічними системами/іх елементами.

Необхідно зазначити, що принцип комплементарності повинен забезпечити синкретичну єдність управлінських процесів, керуючих підсистем та нерозривність управління на територіальному рівні.

Conclusions. На основі методологічного підходу тлумачення діяльності як способу реалізації сутності діючого суб'єкту, здійснено пошук іманентних властивостей феномену місцевого самоврядування. Доведено, що атрибутивною ознакою феномену МC i, відповідно, органів місцевого самоврядування як його проявів та елементів, $є$ комплементарність. Комплекс діяльностей ОМС є послідовністю станів реалізовуваної сутнісної властивості ОМС, якою є комплементарність. Під комплементарністю ОМС розуміємо їх атрибутивну властивість виступати суб' єктом взаємодоповнення та взаємовпливів в часовому континуумі. Обгрунтовано, що влучним терміном для позначення діяльності органів місцевого самоврядування $є$ поняття «комплементарних змін», що описує динамічну складову процесу реалізації функцій системи місцевого самоврядування, яка здатна призвести до оптимального стану взаємодії системи місцевого самоврядування та іiі елементів 3 іншими відкритими динамічними системами та їх елементами.

Визначено сутність інституціональної та функціональної комплементарності системи МС. Інституціональна комплементарність системи МС передбачає вибудуваний і закріплений у законодавстві спосіб реалізації взаємодії з іншими органами публічного управління як місцевого, так і центрального рівнів. Інституціональна комплементарність свідчить про організаційну іманентну єдність декількох відносно стабільних систем і не відображає їх рух у часі. Атрибутивними рисами функціональної комплемен-тарності системи місцевого самоврядування є наступні: вона характеризує процес; може формуватися і використовуватись ситуативно (на основі принципів організаційної і правової автономії) в якості механізму «відповіді» на той чи інший «виклик», що постає перед будь-яким елементом системи місцевого 
самоврядування; на відміну від інституціональної, іiі ініціаторами і суб'єктами може виступати не тільки легітимізована керуюча підсистема, але і будь-який інший (група інших) елементів системи місцевого самоврядування. Визначено статус категорії комплементарності в якості універсальної і ключової темпоральної властивості місцевого самоврядування. Принцип універсальності означає, що місцеве самоврядування завжди, у будь-якій точці часу (квантовому елементі) $\epsilon$ комплементарно відкритим до взаємовпливів з іншорідними системами або їх елементами. Особливість «ключової» темпоральної властивості означає наявність ряду інших, які є вторинними та уточнюючими, що деталізують генеральну.

Виявлено специфічну властивість феномену місцевого самоврядування, якою $є$ постійно реалізовувана у часі здатність, актуалізована спроможність виступати центром комплементарних зв'язків, головним актором комплементарних процесів. Обгрунтовано, що ефективним вектором розвитку системи місцевого самоврядування є реалізація принципу комплементарності шляхом вільного (на основі принципів організаційної та правової автономії) вибору оптимального комплементора - доцільного на певний період часу суб'єкту II, який буде найбільш домірним для суб'єкта I, що представляє систему місцевого самоврядування.

Перспективи подальших наукових досліджень пов'язані із обгрунтуванням парадигмальних характеристик місцевого самоврядування.

\section{Список літератури:}

1. Аршинов В. И. Синергетика конвергирует со сложностью [Электронный ресурс] / Аршинов В. И. // Вопросы философии. - Режим доступа: http://vphil.ru/index.php?option=com_content\&task=view\&id=301\&Itemid=52

2. Атаманчук Г. В. Управление: сущность, ценность, эффективность: учеб. пособие для вузов / Г. В. Атаманчук. - М.: Академический Проект; Культура, 2006. - 544 с.

3. Балабаниць А. В. Технологія планування стратегічних змін у системі управління маркетингом взаємодії підприємств / А. В. Балабаниць, Д. В. Сай // Теория и практика управления. Экономика и управление. - 2014. № $1 .-$ C. $30-35$.

4. Бир С. Кибернетика и менеджмент: пер. с англ. / Стаффорд Бир; под ред. А. Б. Челюсткина, предисл. А. Н. Отоцкого. - Изд. 3-е. - М.: КомКнига, 2010. $-280 \mathrm{c}$.

5. Бор Н. Вибрані наукові праці / Нільс Бор // Статті 1925-1961 рр. - М.: Наука, 1971. - Т. 2. - С. 393. 


\section{Koltun Viktoriia}

6. Герасимова Е. Б. Аналитический инструментарий самооценки устойчивости банка / Е. Б. Герасимова // Вопр. современной науки и практики. 2009. - № 9 (23). - С. 124-132.

7. Глухих Л. В. Реализация комплементарной стратегии посредством конкурентного механизма ведения бизнеса [Електронний ресурс] / Л. В. Глухих, Д. Я. Родин, Е. П. Астахова // Научный журнал КубГАУ. - 2014. - № 101(07). Режим доступу: http://ej.kubagro.ru/2014/07/pdf/21.pdf

8. Дрьоміна Н. В. Юрисдикція міжнародних кримінальних судів і трибуналів: дис. ... канд. юрид. наук: спец. 12.00.11 / Дрьоміна Наталія Вікторівна. Київ, 2006. - 240 с.

9. Завершинск К. Ф. Методологическая комплементарность в исследовании символических матриц динамики политических институтов [Електронний ресурс] / К. Ф. Завершинск // Полис. Полит. исслед. - 2003. - № 1. - С. 39. Режим доступу: http://www.politstudies.ru/article/ 3153?printmode

10. Колтун В. С. Закономірності та тенденції розвитку місцевого самоврядування: комплементарний підхід: монографія / В. С. Колтун. - К.: НАДУ; Вид-во» Фенікс «, 2015. - 365 с.

11. Концепція реформування місцевого самоврядування та територіальної організації влади в Україні [Електронний ресурс]: схвалена розпорядженням Кабінету Міністрів України від 1 квіт. 2014 р. № 333-р. - Режим доступу: http://zakon2.rada.gov.ua/laws/show/333-2014-\%D1\%80

12. Кораблинова И. А. Комлементарные формы отношений между компаниями и потребителями в сфере инфокоммуникаций [Електронний ресурс] / И. А. Кораблинова, М. В. Лиходед, А. И. Цапко. - Режим доступу: http://www.rusnauka.com/19 TSN_2014/Economics/6_173439.doc.htm

13. Корчевна Л. О. Проб̆лема різноджерельного права: дослід порівняльного правознавства: дис. ... д-ра юрид. наук: спец. 12.00.01 - теорія та історія держави і права; історія політичних і правових учень / Корчевна Л. О. - Одеса, 2005. $-412 \mathrm{c}$.

14. Круглов I. Ландшафт як геоекосистема / I. Круглов // Вісн. Львів. ун-ту. - 2006. - Вип. 33. - С. 186-193. - (Серія географічна).

15. Лейбниц Г. В. Сочинения / Г. В. Лейбниц. - М., 1982-1989.

16. Липов В. В. Методологические основы исследования комплементарного взаимодействия рынка и государства [Електронний ресурс] / В.В.Липов//Теоретическаяэкономика.-№4.-2011.-С.76-80.-Режимдоступу: www.theoreticaleconomy.info

17. Назаров А. І. Принцип комплементарності у медіа-освіті / А. І. Назаров [Електронний ресурс] // Устойчивое развитие: наука и практика: междунар. 2014. - Вып. 1 (12). - Ст. 14. - Режим доступу: www.yrazvitie.ru

18. Налимов В. В. Вероятностная модель языка: о соотношении естественных и искусственных языков / В. В. Налимов. - Томск: Томск-М, 2003. - 368 с.

19. Пілевич Д. С. Сутність комплементарної інвестиційної політики держави [Електронний ресурс] / Д.С. Пілевич // Вісн. Чернігів. Нац. технолог. ун-ту. Режим доступу: http://vistnic.stu.cn.ua/index.pl?task=arcl\&l= ua\&j=31\&id=16

20. Пригожин И. Р. От существующего к возникающему: Время и сложность в физических науках / И. Р. Пригожин. - М., 1985. 


\section{Complexity as the immunental properties of local self-governance...}

21. Советский энциклопедический словарь / гл. ред. А. М. Прохоров. 4-е изд. - М.: Сов. энциклопедия, 1989. - 1632 с

22. Фатеева С. В. Комплементарность в экономической культуре: понятие, формы и механизм действия: автореф. дисс. ... д-ра филос. наук: спец. 24.00.01. / Фатеева С. В. - Ростов-н/Д., 2006. - 48 с.

23. Философский энциклопедический словарь. - М.: ИНФРА-М, 1997. $576 \mathrm{c}$.

24. Шеметов П. В. Теория организаций: учеб. пособ. / П. В. Шеметов, С. В. Петухова. - М.: Изд-во «Омега-Л», 2008. - 282 с.

25. Шоркин А. Д. Схемы универсума и генезис научной рациональности / А. Д. Шоркин // Филос. и социолог. мысль. - 1989. - № 3. - С. 22-33.

26. Шухов А. Метрологический факт и общая теория комплементарности [Электронный ресурс] / А. Шухов // Философский портал 2012: электрон. журн. - Режим доступа: http://nounivers.narod.ru/

27. Amable B. Institutional complementarity and diversity of social systems of innovation and production / B. Amable // Review of International Political Economy. - 2000. -V. 7, Issue 4. - P. 645-687.

28. Aoki M. Contingent Governance of Teams: Analysis of Institutional Complementarity / M. Aoki // International Economic Review. - 1994. Vol. 35. - P. 657-676.

29. Bernstein R. J. The New Constellation. The Ethical-Political Horizons of Modernity / R. J. Bernstein // Postmodernity. - Cambridge, 1991. - P. 8.

30. Hall P. An introduction to varieties of capitalism / P. Hall, D. Soskice // Varieties of capitalism: the institutional Foundations of Corporative Advantage. Oxford: Oxford University Press, 2001. - P. 1-68.

31. Robertson R. Glocalization: Time-space and homogeneity - heterogeneity / R. Robertson // Global Modernities. - 1995.

\section{References:}

1. Arshynov V.I. (2011). Sinergetika konvergiruet so slozhnost'ju [Synergetics converges with complexity]. Questions of Philosophy. Vol. 4, pp. 73-84.

2. Atamanchuk G. V. (2006). Upravlenie: sushhnost', cennost', jeffektivnost' [Management: essence, value, efficiency]. Moscow: Akademicheskij Proekt; Kul'tura (in Russian)

3. Balabanycj A. V., Saj D.V. (2014). Tekhnologhija planuvannja strateghichnykh zmin u systemi upravlinnja marketynghom vzajemodiji pidpryjemstv [Technology of planning of strategic changes in the system of management of marketing interaction of enterprises]. Theory and Practice of Management. Economics and Management. vol. 4, pp. 30-35.

4. Bir S. (2010). Kibernetika i menedzhment [Cybernetics and management]. Moscow: KomKniga. (in Russian).

5. Bor N. (1971). Izbrannye nauchnye trudy [Selected scientific works]. Moscow: Nauka. (in Russian)

6. Gerasimova E. B. (2009). Analiticheskij instrumentarij samoocenki ustojchivosti banka [Analytical tool for self-assessment of bank's sustainability]. Issues of modern science and practice. Vol. 9, no. 23, pp. 124-132. 


\section{Koltun Viktoriia}

7. Gluhih L. V., Rodin D. Ja., Astahova E. P. (2014). Realizacija komplementarnoj strategii posredstvom konkurentnogo mehanizma vedenija biznesa [Implementation of the complementary strategy through the competitive mechanism of doing business]. Nauchnyj zhurnal KubGAU [Scientific magazine KubGAU] (electronic journal). Vol. 07, no.107. Retrieved from: http://ej.kubagro.ru/2014/07/pdf/21.pdf/. Accessed: 08.03.2018.

8. Drjomina N. V. (2006). Jurysdykcija mizhnarodnykh kryminaljnykh sudiv $i$ trybunaliv [Jurisdiction of International Criminal Courts and Tribunals] (PhD Thesis). Kyiv: Kyjivsjkyj nacionaljnyj un-t im. Tarasa Shevchenka

9. Zavershinsk K.F. (2003). Metodologicheskaja komplementarnost' v issledovanii simvolicheskih matric dinamiki politicheskih institutov [Methodological complementarity in the study of semimonetary matrices of the dynamics of political institutes]. Polis. Polit. Issled [Polic. political research] (electronic journal). Vol.1, p. 39. Retrieved from: http://www.politstudies.ru/article/ 3153?printmode. (accessed 08.03.2018)

10. Koltun V. S. (2015). Zakonomirnosti ta tendenciji rozvytku miscevogho samovrjaduvannja: komplementarnyj pidkhid [Policies and Trends in Local SelfGovernment Development: A Complementary Approach]. Kyiv: Feniks.

11. Koncepcija reformuvannja miscevogho samovrjaduvannja ta terytorialjnoji orghanizaciji vlady v Ukrajini (2014). [The Concept of Reforming Local SelfGovernment and Terriyal Organization of Power in Ukraine]. (Electronic resource). Retrieved from: http://zakon2.rada.gov.ua/laws/show/333-2014-\%D1\%80 (accessed: 08.03.2018).

12. Korablinova I. A., Lihoded M. V., Capko A. I. (2014). Komlementarnye formy otnoshenij mezhdu kompanijami i potrebiteljami v sfere infokommunikacij [Complementary form of relations between companies and consumers in the field of infocommunications] Jekonomicheskie nauki / 6. Marketing i menedzhment [Economics Sciences / Marketing and management] (electronic journal). Odesskaja nacional'naja akademija svjazi im. A.S. Popova [Odessa National Academy of Communications named after A.S. Popov]. Retrieved from: http://www.rusnauka.com/ 19_TSN_2014/Economics/6_173439.doc.htm. (accessed: 08.03.2018).

13. Korchevna L. O. (2005). Problema riznodzhereljnogho prava: doslid porivnjaljnogho pravoznavstva [The problem of multi-source law: the test of comparative law] (PhD Thesis). Odesa: Nauka.

14. Krughlov I. (2006). Landshaft jak gheoekosystema [Landscape as a geocosystem]. Visn. Ljviv. un-tu [Bulletin of the University of Lvivs]. vol. 33, pp. 186-193.

15. Lejbnic G. V. (1989). Sochinenija [Compositions]. Moscow: Nauka. (in Russian)

16. Lipov V. V. (2011). Metodologicheskie osnovy issledovanija komplementarnogo vzaimodejstvija rynka i gosudarstva [Methodological basis is the study of complementary interaction between the market and the state]. / В. В. Липов // Teoreticheskaja jekonomik [Theoretical economics]. (electronic journal). Vol. 4., pp. 76-80. (electronic journal). Retrieved from: www.theoreticaleconomy.info (accessed: 08.03.2018).

17. Nazarov A. I. (2014). Princip komplementarnosti v mediaobrazovanii [Principle of complementarity in media education]. Ustojchivoe razvitie: nauka 


\section{Complexity as the immunental properties of local self-governance...}

$i$ praktika [Sustainable development: science and practice]. (electronic journal). Vol. 1, no. 12, p. 14. Retrieved from: www.yrazvitie.ru. Accessed: 08.03.2018.

18. Nalimov V. V. (2003). Verojatnostnaja model' jazyka: o sootnoshenii estestvennyh $i$ iskusstvennyh jazykov [Probabilistic model of language: the relationship of natural and artificial languages]. Tomsk: Tomsk-M.

19. Pilevych D. S. (2013). Sutnistj komplementarnoji investycijnoji polityky derzhavy [The Suit of the Complementary Enlightenment of Power]. Visnyk Chernighivsjkogho derzhavnogho tekhnologhichnogho universytetu. Serija "Ekonomichni nauky" [News of the Chernigiv State Power Engineering University. Серія «Економічні науки»].(electronic journal). Vol. 4, no. 70. p. 67. Retrieved from: http://vistnic.stu.cn.ua/index.pl?task=arcl\&l=ua\&j=31\&id=16. Accessed: 08.03.2018.

20. Prigozhin I. R. (1985). Ot sushhestvujushhego $k$ voznikajushhemu: Vremja $i$ slozhnost' $v$ fizicheskih naukah [From the existing to the emerging: Time and complexity in the physical sciences]. Moscow: Nauka. (in Russian)

21. Prohorov A. M. (1989). Sovetskij jenciklopedicheskij slovar' [Soviet Encyclopedic Dictionary ]. Moscow: Sov. Jenciklopedija.

22. Fateeva S. V. (2006). Komplementarnost'v jekonomicheskoj kul'ture: ponjatie, formy $i$ mehanizm dejstvija [Complementarity in economic culture: the concept, forms and mechanism of action] (PhD).

23. Filosofskij jenciklopedicheskij slovar' (1997). [Philosophical Encyclopedic Dictionary ]. Moscow: INFRA-M.

24. Shemetov P.V., Petuhova S.V. (2008). Teorija organizacij [Theory of Organizations].Moscow: Omega-L

25. Shorkin A. D. (1989). Shemy universuma i genezis nauchnoj racional'nosti [Schemes of the universe and the genesis of scientific rationality]. Filos. $i$ sociolog. mysl' [Philosophical and sociological thought]. - vol. 3., pp. 22-33.

26. Shuhov A. (2012). Metrologicheskij fakt i obshhaja teorija komplementarnosti [Meteorological fact and the general theory of complementarity]. Filosofskij portal 2012 [Philosophical portal 2012]. Philosophical portal 2012 (electronic journal). Retrieved from: http://nounivers.narod.ru/ (accessed 08.03.2018).

27. Amable B. Institutional complementarity and diversity of social systems of innovation and production / B. Amable // Review of International Political Economy. - 2000. - V. 7, Issue 4. - P. 645-687.

28. Aoki M. Contingent Governance of Teams: Analysis of Institutional Complementarity / M. Aoki // International Economic Review. - 1994. Vol. 35. - P. 657-676.

29. Bernstein R. J. The New Constellation. The Ethical-Political Horizons of Modernity / R. J. Bernstein // Postmodernity. - Cambridge, 1991. - P. 8.

30. Hall P. An introduction to varieties of capitalism / P. Hall, D. Soskice // Varieties of capitalism: the institutional Foundations of Corporative Advantage. Oxford: Oxford University Press, 2001. - P. 1-68.

31. Robertson R. Glocalization: Time-space and homogeneity - heterogeneity / R. Robertson // Global Modernities. - 1995. 